\title{
Dialogue
}

http://journals.cambridge.org/DIA

Additional services for Dialogue:

DIALOGUE

Revue

canadienne de

philosophie

Email alerts: Click here

Subscriptions: Click here

Commercial reprints: $\underline{\text { Click here }}$

Terms of use : $\underline{\text { Click here }}$

\section{Respect-Worthiness and Dignity}

CAROL HAY

Dialogue / Volume 51 / Issue 04 / December 2012, pp 587 - 612

DOI: 10.1017/S0012217313000073, Published online: 30 May 2013

Link to this article: http://journals.cambridge.org/abstract_S0012217313000073

How to cite this article:

CAROL HAY (2012). Respect-Worthiness and Dignity. Dialogue, 51, pp 587-612 doi:10.1017/S0012217313000073

Request Permissions : $\underline{\text { Click here }}$ 


\title{
Respect-Worthiness and Dignity
}

\author{
CAROL HAY University of Massachusetts Lowell
}

\begin{abstract}
I argue that failing to fulfill the Kantian obligation to protect one's rational nature might actually vitiate future instances of this obligation. To avoid this conclusion, I argue that, contrary to the received view among Kant scholars, the feature in virtue of which someone has unconditional and incomparable value is not the same feature in virtue of which she is owed the respect that constrains how she may be treated. Even though someone who fails to attempt to protect her rational nature fails to respect herself, and even though this moral failing does make her lose a certain kind of value, her obligations to respect herself remain.
\end{abstract}

RÉSUMÉ : Je soutiens que le fait de manquer au devoir kantien de protéger sa propre nature rationnelle pourrait vicier les instances futures de ce devoir. Pour éviter cette conclusion, je soutiens, contrairement au consensus établi parmi les spécialistes de Kant, que la caractéristique qui confère à une personne sa valeur inconditionnelle et incomparable n'est pas la même que celle en vertu de laquelle cette personne mérite le respect qui délimite le traitement qui lui est dû. Bien qu'une personne manquant à son devoir de protéger sa nature rationnelle ne se respecte pas, et bien que cet échec moral lui fasse perdre un certain type de valeur, ses obligations au respect de soi demeurent.

Is it possible for someone to degrade herself to the point where she is no longer owed moral respect? If this is possible, then there is a concern that past failures to fulfill the obligation of self-respect could vitiate future instances of this obligation. Someone who fails to respect herself might literally become unworthy of respect. This is the question I will take up here: whether someone's self-loathing or servile behaviour can ever undermine the obligations others have toward her, or whether it can undermine the obligations she has toward herself. This possibility is a particular problem, I contend, for anyone committed to a Kantian moral framework, according to which, most scholars argue,

Dialogue 51 (2012), 587-612.

(C) Canadian Philosophical Association/Association canadienne de philosophie 2012 doi:10.1017/S0012217313000073 
it is a person's capacity for moral decision-making that both gives her dignity and makes her deserve moral respect.

The quick details of my alternative Kantian proposal are as follows. People are worthy of the sort of respect that constrains how they may be treated (i.e., in Kantian terms, they are ends-in-themselves, or, are respect-worthy) in virtue of something very minimal: their capacity to set and pursue ends according to reason (i.e., in Kantian terms, their humanity). People have unconditional and incomparable value (i.e., in Kantian terms, they have dignity), however, only insofar as they successfully exercise this capacity in a particular way, i.e., insofar as they act morally (i.e., in Kantian terms, insofar as they have personality, or autonomy). Because Kant is notoriously inconsistent with this terminology, Kant scholars have long puzzled over how best to understand Kant's views on the relationship between respect-worthiness and dignity. What is novel about this interpretation is that respect-worthiness and dignity actually come apart, and while people have the former merely in virtue of possessing certain quite minimal rational capacities they have the latter only insofar as they manage successfully to use these capacities in the right way. The view that respect-worthiness and dignity are functionally co-extensive has been articulated by such varied commentators as Richard Dean, Paul Guyer, Thomas Hill, Christine Korsgaard, and Allen Wood, among others. ${ }^{1}$

My interpretation flies in the face of all of these views. In effect, I intend to chart a middle ground between the standard Kantian view that a person's dignity is grounded in her rational nature (which view is made problematic after the recognition that Kant himself clearly suggests that a person can lose her dignity), and the more radical view that a person deserves no respect whatsoever unless she is a good person. This interpretation is required, I contend, if we are to offer a satisfactory moral explanation of what is going on when people damage their rational capacities but still warrant our ethical regard. This interpretation also helps make sense of certain provocative passages in the Metaphysics of Morals and Lectures on Ethics where Kant appears to have different conceptions of the sort of respect he thinks people are owed.

But let us begin with an example of the sort of case I have in mind. "Tralala," one of the short stories in Hubert Selby's Last Exit to Brooklyn, is the story of a young woman, Tralala, who lives in Brooklyn in the 1940 's. ${ }^{2}$ The story begins when Tralala is 15 , when she discovers that if she has sex with the neighbourhood boys they will buy her cigarettes and take her to the movies. This progresses to helping the boys rob neighbourhood drunks, then to helping them rob soldiers on leave. Tralala often acts as bait, leading these men off to a dark alley or abandoned lot where the boys can jump them. Some of these robberies are brutal. They hit the men over the head with bricks. Leave them for dead. Eventually, many of the neighbourhood boys are arrested and Tralala tires of sharing her take with the others. And so she starts out on her own. She picks up johns - usually drunken soldiers on leave-waits until they pass out (or hits 
them over the head with a bottle to speed up the process), and then steals their money. She is young and beautiful and has her pick of the men in the bars she frequents. Months pass, then years. Things spiral downward. She stops having her pick of the drunks in the nicer bars. She loses her fancy clothes. She gets kicked out of the nicer bars. And then the not-so-nice ones. She stops bathing, starts drinking constantly, and will have sex with anyone who will give her a place to sleep for the night. And still she goes on, stealing what she can from whoever she can. One night she finds herself back at the bar where she had started out. The story ends there with a horrifying depiction of Tralala being brutally gang-raped.

Let me tip my hand for the forthcoming discussion of self-respect: there is nothing Tralala could have done to deserve this. Certainly, she has behaved immorally on many occasions. In one of the story's most memorable scenes, for example, she laughs at and spits on a sobbing man who she has just robbed and who her friends have just beaten to within an inch of his life. She is callous and heartless; she preys on men who are naïve, weak, and vulnerable. And in addition to behaving immorally toward others, we might even think she has behaved immorally toward herself - that she has failed to respect herself by allowing her life to spin out of control, by trading sex for movie tickets, cigarettes, and beer money. But nothing she has done-nothing she could docould justify being gang-raped and left for dead.

The story of Tralala motivates two thoughts, I think. The first is that when someone fails to respect herself she can degrade herself to the point where she has lost something that is of great value. The second is that no matter what someone does - no matter how immoral or degraded she has become-she is still owed a certain kind of respect. I think almost everyone would intuitively chafe against the suggestion that there is anything someone could do to make it such that we had no moral obligations toward her. Even the vilest of people do not forfeit their moral rights. This is because the judgement that someone has acted immorally by failing to respect herself does not, we usually think, undermine the basic moral obligations we have toward her. This much is a moral platitude.

But, I will argue, a surprising implication of the received interpretation of Kant's practical philosophy-where most commentators agree that it is a person's capacity to act rationally that gives her moral value and thus makes her deserving of moral respect - is that people who fail to respect themselves can actually fail to deserve moral respect. Though defenders of this received view would of course be reluctant to concede this, I will demonstrate that it follows from their interpretation that people who fail to act morally can lose whatever value it is that makes them deserve the respect that would constrain others' behaviour toward them. This, clearly, will not do. So I intend to offer an alternative interpretation of Kant's views.

According to this alternative interpretation, the feature of people in virtue of which they have unconditional and incomparable value is not the same feature 
in virtue of which they are owed the respect that constrains our treatment of them. This means, among other things, that a Kantian can maintain both (1) that someone loses an important sort of value when she acts in certain immoral self-disrespecting ways, and (2) that no matter how immoral someone is she cannot lose whatever it is that forbids us from treating her however we would like. And because the reasons in virtue of which people are valuable and that they are owed respect apply in the same way to oneself as they do to other people, this implication applies to the obligations we have to ourselves as well as the obligations we have to others. When someone fails to act morally toward herself, this does not vitiate her obligation to respect herself, even though at the same time her failure to do so does make her lose a certain kind of value.

Let me make explicit that I think the analysis I will provide here probably also applies in a straightforward manner to immorality that is directed toward others, not merely to immorality that is self-directed. But, both because I think the problem at hand is most intuitively strong when it comes to self-directed immorality, and because, as we will see, Kant himself seems to think the problem is most acute with respect to self-directed immorality, my central focus will be on failures to treat oneself in a morally acceptable manner, not on failures to treat others acceptably. I should also say that I think the value of what I say here does not hang entirely on whether I can conclusively defend my interpretation of Kant himself. I think something very much like this point was intended by Kant, and I attempt to show that his usage of certain key terms maps on to the distinctions I am making. Still, even if I am wrong and this is not what Kant had in mind, the account I offer here allows a Kantian to explain the intuition that someone's failure to respect herself does not undermine our basic moral obligations to her.

\section{Respect-Worthiness and Dignity}

My Kantian proposal is this. People are worthy of the sort of respect that constrains our treatment of them (i.e., they are respect-worthy) in virtue of something very minimal: their capacity for setting and pursuing ends according to reason. People have unconditional and incomparable value (i.e., they have dignity), however, only insofar as they successfully exercise this capacity in a particular way, that is, insofar as they act morally. What is novel about this proposal is that I am suggesting that respect-worthiness and dignity should come apart, and that while people have the former merely in virtue of possessing certain quite minimal rational capacities, they have the latter only insofar as they manage successfully to use these capacities in the right way.

Something very much like this idea is behind a distinction that Stephen Darwall has articulated. Darwall distinguishes two very different kinds of respect that can be owed to persons: (1) recognition respect, which is a matter of properly recognizing the fundamental features of a person in virtue of which she is owed basic moral respect and respecting her accordingly by being willing to constrain one's behaviour toward her; and (2) appraisal respect, 
which is a matter of evaluating a person's conduct or character and respecting her insofar as she measures up to certain standards of human excellence. ${ }^{3}$ Appraisal respect is owed to persons only insofar as they earn it through what they do or who they are and so is a sort of respect that one can lose or can have in degrees; by contrast, recognition respect is owed to persons just in virtue of their being persons and so can be neither lost nor had in degrees.

I contend that something very much like this idea - that merely having certain capacities calls for a certain type of treatment and attitudes, while having exercised these capacities calls, in addition, for certain other attitudes and treatment-is actually intended by Kant himself. According to the interpretation I want to put forward, the relevant bits of Kantian jargon that map onto these distinctions are humanity for the relevant capacities, personality (or autonomy) for the state of those who have exercised them successfully, end in itself-hood for the sort of value that calls for recognition respect, and dignity for the sort of value that calls for appraisal respect. Kant says that our humanity is an end in itself, and he says that we have dignity insofar as we act morally. Let us look at these claims more closely.

\section{Humanity is an End in Itself}

Kant's account of humanity explains both why people must be respected and what this respect entails. Humanity, for Kant, is not the whole of human nature, but is, rather, a particular subset of characteristics that are often associated with human nature: specifically, those having to do with rational nature. As we will see below, I think it best to understand Kantian humanity in a relatively thin sense as the bare capacity to set and pursue ends. Kant's Formula of Humanity famously commands: "So act that you use humanity, whether in your own person or in the person of any other, always at the same time as an end, never merely as a means" (G 4:429). And the ground, or explanatory justification, of this moral principle is that "[r]ational nature exists as an end in itself" (G 4:429).

The value of humanity, according to Kant, is that it is an end in itself. One of the ways Kant explains what he means in calling humanity an end in itself is by calling it an objective end. ${ }^{5}$ Objective ends, according to Kant, are "a supreme limiting condition in the use of all means" ( $G 4: 438)$ : they place limits both on what other ends we may set and on what means we may use to pursue them. And the demands that objective ends make on us are necessary: they apply regardless of whether we actually want the end. To say that humanity is an objective end, then, is to say that it makes demands on us irrespective of how we feel about it. So one implication of humanity being an end in itself is that there are limits on the ways that beings that possess humanity can be treated. Translating this point into Darwall's terminology, to say that humanity is an end in itself in the sense of being an objective end is to say that humanity demands recognition respect. The recognition that someone possesses rational nature brings with it an obligation to respect her by constraining our behaviour toward her in certain ways. 
When Kant says that humanity is an end in itself, he means to attribute a very particular sort of value to our rational nature - a value that makes it worthy of a kind of respect that places limits on the acceptable ways we can act toward those who have it. But this respect-worthiness is not the only kind of value we have, Kant thinks. We also have what he calls dignity or absolute worth. As I will argue next, Kant attributes this other kind of value to us not merely insofar as we have humanity, but, instead, insofar as we use the capacities that comprise our humanity in a particular way.

\section{Personality has Dignity}

I just argued that Kant thinks humanity is our capacity to act rationally. Many commentators have argued that Kant means to include in his conception of humanity not just our rational capacities but also the successful exercise of these capacities that culminates in moral behaviour. ${ }^{6}$ I want to argue that this way of interpreting Kant runs together important distinctions that are better kept separate.

To see why this is the case, first notice that, despite its potentially misleading label, humanity is just one aspect of human nature. Kant thinks human nature also includes two other distinct elements: animality and personality. ${ }^{7}$ We have animality simply in virtue of being living motile beings; our animality is what explains our instinctual drives. We have personality insofar as we respect the moral law and act from duty alone; as we will see below, personality is what Kant associates with autonomy of the will. Essentially, animality is our capacity to be motivated by instinct ${ }^{8}$ humanity is our capacity to be motivated by reason in general; ${ }^{9}$ and personality is what we have when we are motivated by the moral law in particular. ${ }^{10}$ It is the latter two capacities that concern us most here.

When it comes to our moral nature Kant is far less consistent with his terminology than he is with our animal and rational natures. We just saw that Kant refers to our moral nature as our personality. But in many other places he identifies our moral nature with our autonomy. ${ }^{11}$ The will is autonomous, for Kant, when a rational being's capacity to set and pursue his or her own ends results in a form of self-legislation whereby there are certain moral ends that he or she must set for him- or herself. ${ }^{12}$ We are autonomous, Kant thinks, only when we manage to act morally: when our free wills set and pursue ends that are in accordance with the laws of morality (and are in accordance with our inclinations only contingently, if at all). ${ }^{13}$ Many commentators, however, prefer to understand things slightly differently, interpreting Kantian autonomy as the capacity we have to set laws for ourselves independent of inclination, without reference to whether we actually choose to act on such laws. ${ }^{14}$ On such a view, a person can choose to act immorally, against the laws that her autonomous will has set for herself, but still retain the capacity to set these laws and thus retain her autonomy. The problem with this interpretation, I contend, is that it is not clear how a Kantian can make sense of the idea that someone could 
regard herself as bound by a law that she sometimes chooses not to follow yet still count as autonomous. If someone really has adopted a principle of action, and really does regard herself as bound by it, then on a Kantian conception of motivation she simply could not fail to follow this maxim and still count as autonomous. That is, in not following the principle she has set for herself, she would show herself to be acting heteronomously rather than autonomously. And thus, while understanding autonomy as mere freedom of the will might be closer to what a layperson outside the sphere of Kant interpretation means by autonomy, I do not think there is sufficient evidence to support the view that Kant himself understood autonomy in this way. Interpreting autonomy to require success in acting morally means, admittedly, that Kantian autonomy ends up being something very different from what we might ordinarily think of as autonomy. ${ }^{15}$ But there is, I think, a great deal of textual evidence to support this interpretation: we are autonomous, for Kant, when we actually act rationally (and thus morally), not just when we have the capacity to do so. Kant says that autonomy is "the will's property of being a law to itself" ( $G$ 4:447), and that "the principle of autonomy is ... to choose only in such a way that the maxims of your choice are also included as universal law in the same volition" ( $G$ 4:440). And being able to universalize the maxims of your actions is, of course, the test of the whether your actions are moral: " $[\mathrm{m}]$ orality is ... the relation of actions to the autonomy of the will, that is, to a possible giving of universal law through its maxims" ( $G$ 4:439). Autonomy, for Kant, is not the mere capacity to choose rationally; rather, autonomy is the successful exercise of this capacity, which is possible for us to achieve, but is something we can and do fail to achieve all the time. Autonomy is something we must strive for, not something we merely possess in virtue of our rational powers. ${ }^{16}$

I do not intend to give a detailed analysis of exactly what the difference between the concepts of autonomy and personality amounts to. These terms will be, for my purposes here, interchangeable. What I want to highlight is that Kant consistently uses both of these terms to refer to our moral nature, that he uses both of these terms to refer to the idea that acting morally requires acting independently of inclination, and that he uses both of these terms to support the idea that insofar as we act morally we have a particular sort of value. For clarity's sake, in what follows I will impose some consistency by using the term "personality" to refer to our moral nature. And I will argue that it is our personality, understood as success in acting morally, that Kant thinks gives us dignity.

Kant attributes to us a very special kind of value-dignity, or absolute worth -insofar as we act morally. ${ }^{17}$ What has dignity is of unconditional worth (it is valuable even if no one happens to value it) and incomparable worth (it is literally priceless). ${ }^{18}$ Because we have dignity, Kant thinks we are valuable even if no one values us, and he thinks we cannot rationally be traded away for anything else. ${ }^{19}$ Dignity is a sort of value that exists over and above the value of being worthy of treatment-constraining respect. Things that have dignity are, of course, also always respect-worthy, because the rational capacities that 
give someone respect-worthiness are required in order to be able to engage in the moral behaviour that gives someone dignity. But it would be a mistake to collapse the two values into one. Claims about the unconditional and incomparable worth we have in virtue of our dignity have implications for how we may permissibly be treated, to be sure. But an attribution of dignity is also a valueascription in its own right, independent of considerations of how this value affects how its bearer may be treated. ${ }^{20}$

It is crucial to notice for the interpretation I am putting forward that Kant does not, strictly speaking, usually ascribe dignity to humanity, or rational nature in general. Instead, Kant ascribes dignity to rational nature only insofar as it is moral - that is, insofar as it has personality or autonomy.

Now, morality is the condition under which alone a rational being can be an end in itself, since only through this is it possible to be a lawgiving member in the kingdom of ends. Hence morality, and humanity insofar as it is capable of morality, is that which alone has dignity ( $G$ 4:435). (Emphasis mine.)

This point has been recognized, but treated very differently, by other commentators. ${ }^{21}$ What I want to emphasize is that Kant is relatively consistent in ascribing dignity to personality rather than to humanity; he is also relatively consistent in saying that it is humanity, not personality, that is an end in itself.

The view I am suggesting here distinguishes being an end in itself from having dignity. The former - end in itself-hood - is what imposes an obligation to respect someone; the latter-dignity - is what gives someone unconditional and incomparable value. One is an end in herself in virtue of her humanity; one has dignity in virtue of her personality. Humanity is our rational nature-our capacity to set and pursue ends on the basis of reason and independently of our desires. Personality, on the other hand, is not the mere capacity to set and pursue ends on the basis of reason; personality is, rather, the successful exercise of this capacity. We achieve personality, then, only when we manage to act morally: when our free wills set and pursue ends that are in accordance with the laws of morality.

\section{More Textual Evidence}

Further evidence that this interpretation fits within Kant's moral framework comes from considering what he says about the possibility of losing one's dignity and whether he thinks a loss of this dignity translates into a loss of the right to demand respect. Would Kant be willing to attribute dignity to even the most self-disrespecting of persons, or does he think it is possible to treat oneself in ways that could cause one to lose so much of one's dignity that one is no longer deserving of respect?

Kant does sometimes speak as if someone can lose her dignity if she fails to treat her humanity in certain ways. In fact, almost all of the places where Kant says that one is in danger of losing one's dignity are not those where one 
behaves immorally toward others, but rather those where one behaves immorally toward oneself. ${ }^{22}$ Kant insists that "a man who fails in his duty to himself loses worth absolutely," that "a person [who] allows himself to be treated as a thing ... throws away the worth of his manhood," that "we must reverence humanity in our own person, because apart from this man becomes an object of contempt, worthless in the eyes of his fellows and worthless in himself," and that one's "actions must be in keeping with humanity itself if he is to appear in his own eyes worthy of inner respect" ( $L E 118,119,121,125)$. These passages suggest that Kant does think that one can put herself in danger of losing her dignity by acting in certain ways toward herself: one risks losing her dignity by failing to respect her own humanity. ${ }^{23}$

Even in those places where Kant says that one loses one's dignity by acting in certain ways towards others, the loss of dignity ultimately comes from a failure to fulfill obligations to the self. For example, in the Doctrine of Virtue Kant argues that lying is a "renunciation by the speaker of his personality ... [that makes] such a speaker ... a mere deceptive appearance of a human being, not a human being himself" ( $D V$ 6:429). A liar, Kant thinks, "has even less worth than if he were a mere thing," and "throws away and, as it were, annihilates his dignity as a human being" ( $D V 6: 429)$. What is wrong with lying, however, is that it is a misuse of one's natural powers of communication-it is a violation of an obligation one has to oneself, not one that one has to others. Furthermore, Kant argues that lying to oneself is even worse than lying to others, because one who is guilty of this "makes himself contemptible in his own eyes and violates the dignity of humanity in his own person" ( $D V 6: 430)$.

It seems clear, then, that Kant does think that one can lose dignity, at least by failing to respect one's own humanity. The next question to ask is whether Kant thinks that a loss of dignity can bring with it a loss of respect-worthiness. When it comes to the dignity one might lose by behaving immorally toward others, it is clear that Kant does not think this loss means that one is owed any less respect. He is insistent that even the most immoral and vicious of people can still make demands on how he is permitted to be treated. ${ }^{24}$ No matter how criminal someone's behaviour, we are still constrained in how we may treat him or her. ${ }^{25}$ There is, of course, a sense in which Kant thinks we are permitted to look down on, or think less of, people who act immorally toward others. Kant is not asking us to pretend that it is not the case that some people's actions are better than others or that some people's characters are more virtuous than others. We are certainly permitted to make these sorts of judgements about people. And it is tempting to think of this as a sense in which Kant thinks we are permitted to fail to respect people who act immorally toward others. But it is important to notice that this sense in which we are permitted to refrain from respecting people who act immorally toward others is only the sense in which we are permitted to refrain from according them appraisal respect. We may evaluate such a person's conduct and find it despicable or evaluate her character and find it lacking. These judgements may make us lose a certain kind of 
respect for someone. But the respect that is permissibly lost in such cases is appraisal respect. It is not the sort of respect that constrains our treatment of those to whom it is owed. We are never permitted to refrain from according someone treatment-constraining recognition respect. Whatever loss of dignity might come from behaving immorally toward others, Kant does not think that this loss of dignity ever means one is worth less of the sort of respect that constrains the ways in which one may be treated. And Kant's (infamously) retributivist views on punishment bear this point out. Kant believes respecting someone who has committed an immoral deed is compatible with extremely harsh punishment. But, because a wrongdoer is always still worthy of respect, his punishers are constrained in how they may punish him.

But what about a loss of dignity that results from immoral behaviour directed toward the self? We have just seen that Kant seems to regard this kind of immorality as far more grave than immorality directed toward others, at least insofar as it threatens the perpetrator with a loss of dignity. Might he believe, then, that self-directed immorality, unlike other-directed immorality, could make one lose so much dignity that it could translate into a loss of treatmentconstraining respect-worthiness? Can someone who fails to respect herselfsomeone like Tralala - eventually lose the right to demand respect from others (or from herself)? It seems not, in this case as well. While Kant clearly thinks that one can lose some of her dignity by failing to fulfill one's obligations to oneself, he also insists that one cannot lose all of it. ${ }^{26}$ Even someone who fails to fulfill the obligations she has to herself does not become unworthy of respect. It is simply not possible for someone to degrade herself to the point where she is no longer worthy of the respect that forbids this degradation. As long as someone is alive and has minimally functional rational capacities she is both author of and subject to the moral law, and this is what makes her worthy of the sort of respect that constrains how she may be treated. This, then, is why it is important to endorse a relatively thin, minimal conception of Kantian humanity as the bare capacity to set and pursue ends - because, short of brain death, this capacity is next to impossible for a person to lose. And as long as a person retains her humanity she retains her respect-worthiness. If we interpret Kant in this way we can accommodate fully the moral intuition that has been motivating us here, the thought that just because someone has been immoral this does not mean that we are thereby permitted to treat her however we would like. Since humanity (rather than personality) is an end in itself, we are obligated to respect people - that is, to have recognition respect for them and thus constrain our behaviour toward them-regardless of how they happen to act. ${ }^{27}$

\section{Motivations and Potential Objections}

In addition to its textual plausibility, a significant motivation for this interpretation is that without it Kant's account would be subject to an extremely unintuitive conclusion: if people were to be treated as ends in themselves in virtue 
of their acting morally, rather than in virtue of their capacity to be rational, then people who acted immorally would be less worthy of being treated as ends in themselves. This is, admittedly, not a conclusion that commentators who run together the distinctions I have been at pains to argue that Kant really intends to keep separate would be happy to accept as following from their views. But it is, I contend, a conclusion to which these commentators are committed nevertheless. That is, defenders of the received views of what Kant means by humanity, autonomy, dignity, and respect-worthiness are committed to the conclusion that people who act immorally are worthy of less respect. While there might be a sense in which people are less worthy of respect insofar as they act immorally, this kind of respect - the sort one can gain or lose depending on what she does - is what Darwall would call appraisal respect. This is not the sort of respect that is supposed to attach to humanity, as Kant sees it. This much is clear inasmuch as he calls humanity an objective end (an end that places limits both on what other ends we may set and on what means we may use to pursue any of our ends). Appraisal respect does not constrain our behaviour toward one to whom it is owed; it is merely an evaluation of one's conduct or character. Darwall's recognition respect, on the other hand, makes no reference to a person's actions and does constrain our behaviour toward those to whom it is owed. As we have seen, this is the sort of respect that Kant means to require when he calls humanity an end in itself — particularly insofar as he calls humanity an objective end.

This interpretation fits well with the intuitive thought that our behaviour toward other people is constrained in certain ways simply in virtue of the fact that they are persons, regardless of the immorality of their deeds. It also fits well with the intuitive thought that a person loses a very important kind of value by treating herself (or letting herself be treated) in certain ways, and so there is a sense in which such a person has less dignity. But, at the same time, whatever this loss of value is, it does not, ever, translate into a loss of a person's right to be treated in certain ways, simply in virtue of the fact that she is a certain sort of being.

Notice that this implication applies to the obligations a person has to herself as well. Even if someone like Tralala loses some of her dignity by failing in her obligation to herself to respect her humanity, she nevertheless remains subject to the obligation to respect her humanity. Because the obligation to have respect for humanity applies to the self as well as to others, and because this obligation hinges on one's capacity for rationality, not on how well, morally speaking, one actually exercises this capacity, the obligation of self-respect is not vitiated by a failure to fulfill it. Someone who fails to respect her rational capacities is still morally required to take the steps necessary to respect these capacities, even though at the same time her failure to do so makes her lose a certain kind of worth.

So much for the various motivations for this view; on now, to some potential objections. One potential objection is that while this interpretation might solve 
one problem, it seems to create another. Making humanity rather than personality an end in itself ensures that immoral people are still owed the sort of respect that constrains our behaviour toward them, but making personality rather than humanity be what gives people dignity means that immoral people are in danger of losing their unconditional and incomparable worth. Remember, for Kant, people lose personality when they behave badly. Since people have dignity in virtue of their personality, failing to act morally thereby makes people lose dignity. This seems counterintuitive, to say the least. This sort of value might intuitively seem like the sort of thing that people have regardless of what they do. It seems strange to say that unconditional and incomparable worth can be revoked for bad behaviour. This interpretive strategy might seem especially egregious when it comes to unconditional worth-after all, what is making the attribution of dignity contingent on one's acting the right way, if not imposing a condition upon this worth?

But notice that what Kant says is unconditional in this case is the value of personality, not the attribution of personality to particular individuals with humanity. What has unconditional worth is personality itself, not the individual beings who contingently possess it. So we can say that personality, qua something with the unconditional worth of dignity, has value even if no one happens to value it and at the same time say that the attribution of personality to individual people is a matter of degree and depends upon the extent to which an individual succeeds in conforming her behaviour to the universalizable maxims of morality.

The claim that ascribing dignity to personality rather than to humanity means that one who fails to act morally risks losing some of her dignity is admittedly counterintuitive. But it is the bullet we must bite to solve the interpretive dilemma to which I contend the majority of Kantian commentators are in fact committed. It seems strange, to be sure, to suggest that one's dignity is something that could come and go according to whether one acts according to one's inclinations instead of according to universalizable maxims. But, remember, the respect owed to people is not contingent upon their actions, because people are ends in themselves in virtue of their humanity rather than their personality. Because of this, we can retain the intuitive thought that our behaviour toward others is constrained regardless of how they act.

Another potential problem for the interpretation I am offering here is that on this view we are left without a ground for the respect-worthiness of humanity. I am arguing, remember, that rational nature is respect-worthy regardless of whether it has dignity - that is, regardless of whether someone uses her rational nature to act morally. But then what is the justification for this respectworthiness? If rational nature is not, in itself, unconditionally and incomparably valuable, then why must it always be treated with respect? The received interpretation of Kant's views on this matter has it that the respect our humanity is owed derives straightforwardly from the dignity it has, so this interpretation is 
not subject to this problem. But because I propose to separate the features in virtue of which someone is owed respect from the features in virtue of which she has dignity, and because I argue that someone can be worthy of respect even if she behaves in ways that make her lose dignity, a critic might argue that I am left without a way to explain or justify why someone's rational nature must be respected regardless of what she does with it.

There is, however, a straightforward solution to this problem. As I discussed above, rational nature is a necessary precondition for the possibility of someone acting morally. Rational nature is the one thing you need to have if you are even going to be in the running for having that value which is most morally important (i.e., dignity). ${ }^{28}$ So humanity is always worthy of (treatmentconstraining) respect because it is what makes morality possible. This is, I contend, the best way to interpret the connection between respect-worthiness and dignity: our rational capacities must be respected because they are what make it possible for us to act morally, and insofar as we succeed in acting morally we have the highest possible value.

\section{Some Textual Counterevidence}

My suggestion here, remember, is that Kant means to separate the dignity people have from the respect they are owed and that he does not think that a loss of the former can affect the latter. There are good reasons for adopting this interpretation, I have argued. But I will admit that this interpretation faces what appears to be considerable textual counterevidence. For example, in one place, Kant explicitly says that "morality is an end in itself" (DV 6:422-423), and in several other places he refers to the "dignity of humanity" ( $G 4: 439$; $D V$ 6:420; $D V$ 6:440; $D V$ 6:449) and to "humanity in its proper dignity" (CPR 5:88). I will admit that my interpretation is controversial, and that it certainly does not fit with everything in Kant's texts. It is admittedly not impossible to come up with examples of passages where Kant says things that cut against my interpretation, where he says things other than that it is autonomy that has dignity and humanity that is an end in itself. It is also relatively easy to come up with examples of passages where Kant says things that alternately support and cut against my interpretation. I want to examine several such cases now.

The first example of a passage that alternates between supporting and undermining my interpretation comes from the Critique of Practical Reason. Here, Kant runs together the four distinctions I have been at pains to keep apart:

The moral law is holy (inviolable). A human being is indeed unholy enough but the humanity in his person must be holy to him. In the whole of creation everything one wants and over which one has any power can also be used merely as a means; a human being alone, and with him every rational creature, is an end in itself: by virtue of the autonomy of his freedom is he the subject of the moral law, which is holy (CPR 5:87). 
First he says here that it is in virtue of someone's humanity that she, and every other rational creature, is an end-in-herself. This is precisely the line I have been pushing. But then Kant says that

[j] ust because of this every will, even every person's own will directed to himself, is restricted to the condition of agreement with the autonomy of the rational being, that is to say, such a being is not to be subjected to any purpose that is not possible in accordance with a law that could arise from the will of the affected subject himself; hence this subject is to be used never merely as a means but as at the same time an end (CPR 5:87).

Here he has said that it is the autonomy of rational beings (which, remember, I am interpreting as the successful exercise of one's rational capacities, i.e., as actually acting morally) that qualifies them to "be used never merely as a means but as at the same time an end." I have been arguing that the successful exercise of someone's rational capacities is what gives her dignity, not what means she must always be treated as an end in herself. And he goes on to say that

[w]e rightly attribute this condition even to the divine will with respect to the rational beings in the world as its creatures, inasmuch as it rests on their personality, by which alone they are ends in themselves (CPR 5:87).

He has said here that rational creatures are ends in themselves in virtue of their personality: again, exactly what I am arguing is not the case.

A second example of a passage that alternately supports and undermines my interpretation comes from the Doctrine of Virtue:

The respect that I have for others or that another can require from me (observantia aliis praestanda) is therefore recognition of a dignity (dignitas) in other human beings (DV 6:462).

Immediately, this subverts my interpretation. Kant has said that respect is required by the recognition that someone has dignity, whereas I have been arguing that respect is required by the recognition that a person is an end in itself. Then Kant tells us that

[h] umanity itself is a dignity; for a human being cannot be used merely as a means by any human being (either by others or even by himself) but must always be used at the same time as an end (DV 6:462).

Again, this is contrary to my interpretation: humanity is not supposed to have dignity; autonomy is. What is worse, Kant implies that this dignity is what makes someone an end in herself. But then Kant turns around and says that 
[i]t is just in this that his dignity (personality) consists, by which he raises himself above all other beings in the world that are not human beings and yet can be used, and so over all things ( $D V$ 6:462).

This sits much more nicely with the interpretation I am putting forward. Here, he once again associates dignity explicitly with personality. Unfortunately, he immediately goes on to associate dignity with humanity:

But just as he cannot give himself away for any price (this would conflict with his duty of self-esteem), so neither can he act contrary to the equally necessary selfesteem of others, as human beings, that is, he is under obligation to acknowledge, in a practical way, the dignity of humanity in every other human being ( $D V 6: 462)$.

There is no way to explain this particular instance away. Were my interpretation to be completely uncontroversial, Kant would have had to say here that it is the dignity of the personality in others that we must acknowledge. Kant goes on to say that it follows from this "dignity of humanity" that

[h] ence there rests on him a duty regarding the respect that must be shown to every other human being (DV 6:462).

Notice that it is ambiguous here, whether we owe other people respect because they have humanity (which fits with my interpretation) or because they have dignity (which does not).

A third example of a passage that similarly alternates between supporting and undermining my interpretation is found in what Kant says about the vice of lying in the Doctrine of Virtue. He starts off by saying that

[t]he greatest violation of a human being's duty to himself regarded merely as a moral being (the humanity in his own person) is the contrary of truthfulness, lying (DV 6:429).

If Kant were consistent in using the terminological distinctions I am advocating, a duty to oneself "regarded merely as a moral being" would be to the autonomy in one's own person, not to the humanity in one's own person, as he says here. He goes on to say that when someone lies to himself,

he makes himself contemptible in his own eyes and violates the dignity of humanity in his own person ( $D V 6: 429)$.

Now he has gone and said that the humanity in one's own person has dignity. But I have been suggesting that dignity attaches to autonomy, not to humanity. Humanity is supposed to be what makes one an end in itself, not what gives one 
dignity. None of this bodes well for my suggested interpretation. Kant then tells us that lying does not merely violate one's dignity, it actually destroys it:

By a lie a human being throws away and, as it were, annihilates his dignity as a human being ( $D V 6: 429)$.

At least here he has not said to what the dignity in a human being attaches. This particular line is consistent with dignity attaching to either the humanity or the autonomy in a person. (Though given that this line follows straightaway after the line where he has said that dignity attaches to humanity, we should probably not put too much stock in this ambiguity. There is no real reason to think he has changed his mind so quickly about what dignity attaches to.) Kant goes on to explain exactly what is wrong with lying:

A human being who does not himself believe what he tells another ... has even less worth than if he were a mere thing; for a thing, because it is something real and given, has the properly of being serviceable so that another can put it to some use. But communication of one's thoughts to someone through words that yet (intentionally) contain the contrary of what the speaker thinks on the subject is an end that is directly opposed to the natural purposiveness of the speaker's capacity to communicate his thoughts, and is thus a renunciation by the speaker of his personality, and such a speaker is a mere deceptive appearance of a human being, not a human being himself (DV 6:429). (Emphasis mine.)

Here, finally, we have some support for my interpretation. Lying is, in effect, a perversion of someone's capacity to communicate. This amounts to a renunciation of one's personality, Kant thinks. Personality is what we have when we actually successfully behave morally, remember. Lying is a renunciation of this because it is a failure to do what the moral law requires of us. The ultimate problem with lying, then, boils down to a matter of its effect on one's personality, not one's humanity. This explains why it results in a loss of dignity (which, I am suggesting, attaches to personality instead of humanity).

A fourth and fifth example from the Doctrine of Virtue are similarly ambiguous. Here, Kant says that

a human being's duty to himself as a moral being only (without taking his animality into consideration) consists in what is formal in the consistency of the maxims of his will with the dignity of humanity in his person ( $D V 6: 420)$.

Nearby, he says that

[t]he dignity of humanity consists precisely in this power of giving universal law, though only on condition of also being subject to this same lawgiving (DV 6:440). 
In both of these passages, Kant supports various aspects of my interpretationin the first passage affirming an important distinction between different aspects of our nature (in this case, our moral nature and our animal nature) and associating the duties we have to ourselves in virtue of our moral nature with the special value of dignity, and in the second passage affirming that dignity attaches to our moral capacity to formulate and subject ourselves to universal laws. Unfortunately, however, these are also both passages where Kant locates dignity in humanity rather than personality. As I admitted above, there are a few phrases that unequivocally cut against my interpretation; these are two of those problematic phrases.

And, finally, a sixth example, also from the Doctrine of Virtue, that also both supports and undermines my interpretation:

[A] human being regarded as a person, that is, as the subject of a morally practical reason, is exalted above any price; for as a person (homo noumenon) he is not to be valued merely as a means to the ends of others or even to his own ends, but as an end in itself, that is, he possesses a dignity (an absolute inner worth) (DV 6:434).

So far it looks as if my interpretation is correct: Kant is clearly saying that dignity attaches to personality, that it is properly ascribed to people insofar as they behave morally. But then he goes on immediately to say that this dignity is that

by which [this person] ... exacts respect for himself from all other rational beings in the world ( $D V 6: 434)$.

This fits much less well with my interpretation. Respect-worthiness, I am arguing, is supposed to attach to humanity, not personality. We are able to make claims on the way others are permitted to treat us in virtue of our humanity, I am arguing. It seems that Kant has just denied this and has said instead that it is the dignity we have in virtue of our personality that gives us the right to be respected by others. But then he goes on to say just the reverse:

Humanity in his person is the object of the respect which he can demand from every other human being, but which he must also not forfeit ( $D V 6: 435)$.

Thus Kant ends up saying just what we would expect him to say if my interpretation is the correct one. Once again, it is humanity that grounds the respect that is owed from others, not personality.

As these passages show, my interpretation does not fit seamlessly with the entire Kantian corpus. In a number of places Kant uses the terms "humanity" and "personality" as if they were interchangeable. And he is not always consistent in attributing dignity to personality and end-in-itself-hood to humanity. I do not know how to make these differing strains in Kant completely consistent, 
and I am not aware of a single passage that settles this issue conclusively. However, even if the textual kinks here cannot be ironed out completely, I want to foreground Kant's consistent characterization of humanity as an objective end - an end that places limits on how beings with humanity can be treatedand foreground the fact that Kant usually attributes dignity to autonomy or personality instead of humanity. Doing this suggests that we have reason for thinking that, at least according to what, on my interpretation, is Kant's most considered view, "humanity" and "personality" are not interchangeable, and that the former is what is owed treatment-constraining respect while the latter is what has dignity.

\section{Conclusion}

On the interpretation I have put forward here, Kant ascribes dignity to personality rather than humanity, and he ascribes respect-worthiness to humanity rather than personality. I recognize that I am implying here that someone who fails to respect herself risks losing her dignity. But I am also suggesting that, even if someone loses some of this worth, we are still constrained in how we are permitted to treat her. It is admittedly a bit strange to be forced to admit that the dignity (the unconditional and incomparable worth) one has in virtue of one's personality can be lost through bad behaviour (and thus that it can come in degrees). But I think this is a far more attractive bullet to bite once we realize that, because the constraints upon the way one can be treated are a matter of one's humanity, not personality, the respect one is owed in virtue of one's humanity cannot be done away with, regardless of how one acts.

We came to this problem, remember, because of the worry that failing to fulfill the Kantian obligation to protect one's rational nature might actually vitiate future instances of this obligation. I have responded to this objection by defending a novel interpretation of Kant's views on the relation between the value we have and the respect we are owed. I have argued, contra the received view among Kant scholars, that the feature in virtue of which someone has unconditional and incomparable value is not the same feature in virtue of which she is owed the respect that constrains how she may be treated. So, even though someone who fails to attempt to protect her rational nature fails to respect herself in the right way, and even though this moral failing does make her lose a certain kind of value, her obligations to respect herself do not go away. One can become less valuable insofar as she abuses, defiles, dishonours, or fails to develop aspects of her moral agency, but this loss of value never threatens her moral patiency.

\section{Notes}

1 Richard Dean collapses the distinction between respect-worthiness (i.e., end-initself-hood) and dignity in his rather idiosyncratic interpretation of Kantian humanity: "Kant begins the Groundwork with the claim that only a good will is good without qualification, and that only a good will has incomparably high value, 
or dignity. Later in the Groundwork, he says that only humanity is an end in itself, and only humanity has a dignity. A thorough analysis of these claims reveals that something that has an incomparably high value, and is valuable without qualification, must also be an end in itself. So good will must be the end in itself." See Richard Dean, The Value of Humanity in Kant's Moral Theory, (New York: Oxford University Press, 2006), 8. Paul Guyer's interpretation is more conventional, but he also ends up equating respect-worthiness and dignity when he says, for example, that "the idea of humanity as an end in itself ... is identical to the idea of the incomparable dignity of human autonomy or freedom governed by the law that we give to ourselves." See Paul Guyer, Kant on Freedom, Law, and Happiness, (Cambridge: Cambridge University Press, 2000), 9-10. Thomas Hill does the same when he says, for example, that "humanity in each person has dignity, no matter how immoral the person may be ... . Autonomy is said to be the ground of dignity, and this is a property of the will of every rational being." See Thomas Hill, "Humanity as an End in Itself," Dignity and Practical Reason in Kant's Moral Theory (Ithaca: Cornell University Press, 1992), 47. Christine Korsgaard collapses this distinction when, for example, she argues that dignity attaches to the capacity for acting morally (which she elsewhere characterizes as humanity, which is an end in itself): "If we regard ourselves as having the power to justify our ends, ... we must regard ourselves as having an inner worth [(i.e., dignity)] — and we must treat others who can also place value on their ends in virtue of their humanity as having the same inner worth." See Christine Korsgaard, "Two Distinctions in Goodness," Creating the Kingdom of Ends, (Cambridge: Cambridge University Press, 1996), 273. Allen Wood initially appears to distinguish respect-worthiness from dignity when he says, "[i]f being an end in itself constitutes the worth of humanity - in the technical Kantian sense, which is the capacity to set ends according to reason-then having dignity constitutes the worth of personality — which is the capacity to give oneself moral laws and obey them." But, because he characterizes personality as the capacity to act morally (rather than the successful exercise of this capacity) Wood immediately goes on to say that "Kant nevertheless frequently speaks of the "dignity of humanity" as well as the dignity of personality. Kant usually writes as if humanity and personality were coextensive." This move, in effect, collapses the distinction between respect-worthiness and dignity. See Allen Wood, Kantian Ethics, (Cambridge: Cambridge University Press, 2008), 94.

2 Hubert Selby, "Tralala," Last Exit to Brooklyn (New York: Grove Press, 1957).

3 Stephen Darwall, “Two Kinds of Respect," Ethics 88 (1977): 36-49.

4 Immanuel Kant, Groundwork of the Metaphysics of Morals, ed. and trans. Mary Gregor (Cambridge: Cambridge University Press, 1998 [1785]). “ $G$ ” in parenthetical documentation hereafter refers to this work.

5 "[R]ational beings are called persons because their nature already marks them out as an end in itself, that is, as something that may not be used merely as a means, and hence so far limits all choice (and is an object of respect). These, therefore, are not merely subjective ends, the existence of which as an effect of our action has a worth for us, but rather objective ends, that is, beings the existence of which is in itself an end, 
and indeed one such that no other end, to which they would serve merely as means, can be put in its place, since without it nothing of absolute worth would be found anywhere; but if all worth were conditional and therefore contingent, then no supreme practical principle for reason could be found anywhere" ( $G$ 4:428).

6 See, for example, Richard Dean, The Value of Humanity in Kant's Moral Theory, cited above in note (1), Thomas Hill, Dignity and Practical Reason in Kant's Moral Theory, cited above in note (1), and Mark Timmons, Moral Theory: An Introduction (Lanham: Rowman and Littlefield, 2002).

7 Kant distinguishes the three "elements of the determination of the human being" in the following way: " 1 . The predisposition to the animality of the human being, as a living being; 2 . To the humanity in him, as a living and at the same time rational being; 3. To his personality, as a rational and at the same time responsible being." Immanuel Kant, Religion within the Boundaries of Mere Reason, ed. and trans. Alan Wood and George di Giovanni (Cambridge: Cambridge University Press, 1998[1793]), 6:26. " $R$ " in parenthetical documentation hereafter refers to this work.

8 "Our duties to ourselves on the animal level are to preserve ourselves, preserve the species, and preserve our capacity to enjoy life." Immanuel Kant, "Metaphysical first principles of the doctrine of virtue," The Metaphysics of Morals, ed. and trans. Mary Gregor (Cambridge: Cambridge University Press, 1996 [1797]), 6:420. " $D V$ ", in parenthetical documentation hereafter refers to this work.

9 "The capacity to set oneself an end - any end whatsoever - is what characterizes humanity (as distinguished from animality)" (DV 6:392).

10 "It is nothing other than personality, that is, freedom and independence from the mechanism of the whole of nature, regarded nevertheless as also a capacity of being subject to special laws - namely pure practical laws given by his own reason, so that a person as belonging to the sensible world is subject to his own personality insofar as he also belongs to the intelligible world; for, it is then not to be wondered at that a human being, as belonging to both worlds, must regard his own nature in reference to his second and highest vocation only with reverence, and its laws with the highest respect." Immanuel Kant, The Critique of Practical Reason, ed. and trans. Mary Gregor (Cambridge: Cambridge University Press, 1997 [1788]), 5:86-87. " $C P R$ " in parenthetical documentation hereafter refers to this work.

"A person is a subject whose actions can be imputed to him. Moral personality is therefore nothing other than the freedom of a rational being under moral laws (whereas psychological personality is merely the ability to be conscious of one's identity in different conditions of one's existence). From this it follows that a person is subject to no other laws than those he gives to himself (either alone or at least along with others)." Immanuel Kant, "Metaphysical first principles of the doctrine of right," The Metaphysics of Morals, ed. and trans. Mary Gregor (Cambridge: Cambridge University Press, 1996 [1797]), 6:224. "DR” in parenthetical documentation hereafter refers to this work.

11 "Morality is ... the relation of actions to the autonomy of the will, that is, to a possible giving of universal law through its maxims. ... Our own will insofar as it 
would act only under the condition of a possible giving of universal law through its maxims ... is the proper object of respect; and the dignity of humanity consists just in this capacity to give universal law, though with the condition of also being itself subject to this very lawgiving" ( $G$ 4:439-440).

12 "[W]hat, then, can freedom of the will be other than autonomy, that is, the will's property of being a law to itself?" ( $G 4: 447)$.

"For, this moral law is based on the autonomy of the will, as a free will which, in accordance with its universal laws, must necessarily be able at the same time to agree to that to which it is to subject itself" (CPR 5:132).

13 "Autonomy of the will is the property of the will by which it is a law to itself (independently of any property of the objects of volition). The principle of autonomy is, therefore: to choose only in such a way that the maxims of your choice are also included as universal law in the same volition" ( $G$ 4:440).

14 See, e.g., Anne Margaret Baxley, "Autonomy and Autocracy," Kant-Studien 94 (2003): 1-23; Lara Denis, "Freedom, Primacy, and Perfect Duties to Oneself," Kant's Metaphysics of Morals: A Critical Guide (Cambridge: Cambridge University Press, 2010), 171-172; Thomas Hill, "The Hypothetical Imperative," Dignity and Practical Reason in Kant's Moral Theory, 34-35, cited above in note (1); Mark Timmons, Moral Theory: An Introduction, cited above in note (6).

15 For a careful consideration of many other ways in which the Kantian conception of autonomy differs from other conceptions, see Thomas Hill, "The Kantian Conception of Autonomy," Dignity and Practical Reason in Kant's Moral Theory, 76-96, cited above in note (1).

16 This way of understanding Kantian autonomy is not unprecedented. Stephen Engstrom, for example, argues that "the concept of self-legislation, or autonomy, implies [that] in a rational being the law in accordance with which its (rational) capacities are exercised and the representation of that law are the same." Stephen Engstrom, "Happiness and the Highest Good in Aristotle and Kant," Aristotle, Kant, and the Stoics: Rethinking Happiness and Duty (Cambridge: Cambridge University Press, 1996), 115. Paul Guyer argues that autonomy is "the aim that a person with free will must adopt if he is to preserve and promote his freedom of choice and action ..., which is something such an agent ought to do, and can do, but does not necessarily do." Paul Guyer, "Kant on the Theory and Practice of Autonomy," Social Philosophy and Policy 20 (2003), 71. Christine Korsgaard supports a similar view, arguing that " $[\mathrm{w}]$ hen you are motivated autonomously, you act on a law that you give to yourself; when you act heteronomously, the law is imposed on you by means of a sanction - you are provided with an interest in acting on it." Christine Korsgaard, "Ethical, Political, and Religious Thought," Creating the Kingdom of Ends, (Cambridge: Cambridge University Press, 1996), 22.

17 "For, nothing can have a worth other than that which the [universal] law determines for it. But the lawgiving itself, which determines all worth, must for that very reason have a dignity, that is, and unconditional, incomparable worth; and the word respect alone provides a becoming expression for the estimate of it that a rational being must give. Autonomy is therefore the ground of the dignity of human nature and of every rational nature" ( $G$ 4:436). 
18 "The respect that I have for others or that another can require from me ... is therefore recognition of a dignity ... in other human beings, that is, of a worth that has no price, no equivalent for which the object ... could be exchanged" (DV 6:462).

19 This understanding of dignity is very much in line with how most other commentators understand the concept. See, e.g., Paul Guyer, Kant on Freedom, Law, and Happiness, cited above in note (1), 153-154; Thomas Hill, Dignity and Practical Reason in Kant's Moral Theory, cited above in note (1), chs. 2 and 10, and Respect, Pluralism, and Justice: Kantian Perspectives, (New York: Oxford University Press, 2000), 24-26; Herbert James Paton, The Categorical Imperative (London: Hutchison \& Co., 1947), 189; Allan Wood, Kant's Ethical Thought (Cambridge: Cambridge University Press, 1999), 115. One notable exception to this agreement is Oliver Sensen, who argues that Kantian dignity is not best understood as our absolute inner value, but rather as a "sublimity" that indicates that, in virtue of our capacity for moral action, we are "raised up" above all other creatures. See Oliver Sensen, "Kant's Conception of Human Dignity" Kant-Studien 100 (2009): 309-331.

20 Some commentators interpret value ascriptions in the Kantian moral framework as, in effect, nothing over and above prescriptions about how a thing may permissibly be treated. This would, of course, have the effect of collapsing the distinction between respect-worthiness and dignity. This interpretive move is undermined, however, by a distinction Kant makes between two kinds of respect: Reverentia and Observantia. Reverentia is the feeling of respect that is elicited by our recognition of the moral law or a person who is successfully acting upon it, "in terms of which he is above any price and possesses an inalienable dignity" (DV 6:436). Observantia is "respect in a practical sense," a respect which constrains our treatment of others and is owed to them in virtue of their humanity ( $D V 6: 459,463)$. I am arguing that we should read Kant as telling us that, strictly speaking, Reverentia is owed to personality and Observantia is owed to humanity. Because Reverentia is a subjective feeling, not a treatment, and Kant tells us explicitly that it, like all feelings, cannot be a duty and is instead the subjective condition of the possibility of being susceptible to duty ( $D V 6: 402$ ), we have here a particular response to a recognition of the value of something that cannot be reduced to a prescription about how it must be treated. This means that value ascriptions cannot be reduced to prescriptions about permissible treatment.

In any case, I think it is sufficiently unclear whether Kant himself held respectworthiness and dignity to be co-extensive or distinct to render an interpretation that holds them distinct at least plausible, but I recognize that other Kantians might beg to differ here. Thanks to an anonymous reviewer for pressing me on this point; thanks to Robin Dillon for helpful discussion on this point.

21 See, for example, Paul Guyer, "Kant on the Theory and Practice of Autonomy," cited above in note (16); Thomas Hill, "Humanity as an End in Itself," Dignity and Practical Reason in Kant's Moral Theory, cited above in note (1); Christine Korsgaard, "Ethical, Political, and Religious Thought," Creating the Kingdom of Ends, cited above in note (1); and Allen Wood, Kantian Ethics, cited above in note (1). 
22 "Neither can we without destroying our person abandon ourselves to others in order to satisfy their desires, even though it be done to save parents and friends from death; still less can this be done for money. If done in order to satisfy one's own desires, it is very immodest and unnatural; but if it be done for money, or for some other reason, a person allows himself to be treated as a thing, and so throws away the worth of his manhood. ... The most serious offence against the duty one owes to oneself is suicide." Immanuel Kant, Lectures on Ethics, ed. and trans. Peter Heath (Cambridge: Cambridge University Press, 2001), 119. “ $L E$ ” in parenthetical documentation hereafter refers to this work.

"Far from ranking low in our scale of precedence, our duties towards ourselves are of primary importance and should have pride of place; for ... it is obvious that nothing can be expected from a man who dishonours his own person. He who transgresses against himself loses his manliness and becomes incapable of doing his duty towards his fellows. A man who performed his duty to others badly, who lacked generosity, kindness and sympathy, but who nevertheless did his duty to himself by leading a proper life, might yet possess a certain inner worth; but he who has transgressed his duty towards himself, can have no inner worth whatsoever. Thus a man who fails in his duty to himself loses worth absolutely; while a man who fails in his duty to others loses worth only relatively. It follows that the prior condition of our duty to others is our duty to ourselves; we can fulfil the former only in so far as we first fulfil the latter" (LE 117-118).

"The basis of such obligation is not to be found in the advantages we reap from doing our duty towards ourselves, but in the worth of manhood. This principle does not allow us an unlimited freedom in respect of our own persons. It insists that we must reverence humanity in our own person, because apart from this man becomes an object of contempt, worthless in the eyes of his fellows and worthless in himself. Such faultiness is absolute. Our duties towards ourselves constitute the supreme condition and the principle of all morality; for moral worth is the worth of the person as such; our capacities have a value only in regard to the circumstances in which we find ourselves" (LE 121).

"Our duties to ourselves are negative; they restrict our freedom in respect of our inclinations, which aim at our own welfare. Just as law restricts our freedom in our relations with other men, so do our duties to ourselves restrict our freedom in dealing with ourselves. All such duties are grounded in a certain love of honour consisting in self-esteem; man must not appear unworthy in his own eyes; his actions must be in keeping with humanity itself if he is to appear in his own eyes worthy of inner respect" ( $L E 125)$.

23 Very much in line with this, Lara Denis argues that we should understand Kant as holding that "the preservation, expression, and furtherance of each agent's freedom depends more fundamentally on her compliance with perfect duties to herself than with her compliance with other duties or on others' compliance with their duties toward her. [Perfect duties to the self] concern the protection of basic conditions of agency to an extent unrivaled by other duties. ... The agent is in a unique position to impair her inner freedom and autocracy; to undermine her sense of herself as a 
being with dignity and a subject of the moral law; to forfeit her standing as an honourable human being in the eyes of herself and others; and to imperil the grounds of her virtue. [Perfect duties to the self] are the only duties that forbid actions, vices, or maxims that threaten freedom in these profound and distinctive ways." Lara Denis, "Freedom, Primacy, and Perfect Duties to Oneself," Kant's Metaphysics of Morals: A Critical Guide, cited above in note (16).

Departing somewhat from many interpretations of Kant, I contend that we should think of humanity as an ordinary human capacity, as susceptible to harm as many other human capacities. Our humanity can be harmed both when damage is done to our capacity to set and pursue ends according to reason, and also when we face illegitimate restrictions on the full and proper exercise of this capacity. The former sort of harm occurs when one's rational capacities are prevented from functioning in a way that also threatens their future functioning; the latter sort of harm occurs when one encounters an unfair temporary interference with the full exercise of one's rational capacities. The line between these two sorts of harm will not always be completely clear, but this vagueness is unimportant given our purposes here because Kant clearly believes that both sorts of harm are capable of threatening one's dignity.

24 "To be contemptuous of others (contemnere), that is, to deny them the respect owed to human beings in general, is in every case contrary to duty; for they are human beings. At times one cannot, it is true, help but inwardly looking down on some in comparison with others (despicatui habere); but the outward manifestation of this is, nevertheless, an offense. ... I cannot deny all respect to even a vicious man as a human being; I cannot withdraw at least the respect that belongs to him in his quality as a human being, even though by his deeds he makes himself unworthy of it. So there can be disgraceful punishments that dishonour humanity itself (such as quartering a man, having him torn by dogs, cutting off his nose and ears). Not only are such punishments more painful than loss of possessions and life to one who loves honor (who claims the respect of others, as everyone must); they also make a spectator blush with shame at belonging to the species that can be treated that way. ... The censure of vice ... must never break out into complete contempt and denial of any moral worth to a vicious human being; for on this supposition he could never be improved, and this [is] not consistent with the idea of a human being, who as such (as a moral being) can never lose entirely his predisposition to the good" (DV 6:463-464).

25 "If a man be a rogue, I disapprove of him as a man, but however wicked he is there is still some core of the goodwill in him, and if I distinguish between his humanity and the man himself I can contemplate even the rogue with pleasure. No rogue is so abandoned that he does not appreciate the difference between good and bad and does not wish to be virtuous. The moral feeling and the goodwill are within him, but he lacks the strength and the motive. He may be a most wicked wretch, but who knows what drove him to it. ... If I look into his heart, I can find in him too a feeling for virtue, and therefore in him too humanity must be loved. It can, therefore, be said with full justification that we ought to love our neighbour. ... Since men are 
objects of love, of good-pleasure, in the sense that we ought to love humanity in them, judges ought not when punishing criminals to dishonour their humanity; a miscreant should be punished, but his humanity ought not to be violated by base punishments; for if another dishonours any man's humanity, it as though he has done so himself, as if he were no longer worthy to be a man, so that he must be treated as an object of universal contempt" ( $L E$ 197).

26 "A human being cannot renounce his personality as long as he is a subject of duty, hence as long as he lives; and it is a contradiction that he should be authorized to withdraw from all obligation, that is, freely to act as if no authorization were needed for this action" (DV 6:422-423).

27 I have argued that failing to respect oneself never threatens one's respect-worthiness. Michael J Meyer acknowledges this point, but does not defend any particular Kantian interpretation of it in detail, when he states that " $[t]$ he fact that anyone engages in undignified behaviour or fails to have an appropriate sense of dignity gives no individual moral licence to treat him - even while he is doing so - as if he has no dignity. While we might say of someone who degrades himself that he has "lost his dignity," we nonetheless recognize that this "loss" is not complete in this important sense: it does not provide others with the privilege to treat him like an object or deprive him of the status of a human being." See Michael J. Meyer, "Dignity, Rights, and Self-Control," Ethics 99 (1989): 529.

I have also argued that the Kantian moral framework needs certain distinctions: that we need to be able to capture the idea that merely having certain capacities calls for a certain type of treatment and attitudes, while having exercised these capacities calls, in addition, for certain other attitudes and treatment. Thomas Hill has also recognized the need for similar distinctions in Kant. But because Hill's ways of understanding Kantian humanity, personality, dignity, and respect-worthiness are all different from mine, his interpretative solution to this dilemma is completely different. See Thomas Hill, "Must Respect be Earned?" Respect, Pluralism, and Justice: Kantian Perspectives, cited above in note (21), and "Kant on Imperfect Duty and Supererogation," Dignity and Practical Reason in Kant's Moral Theory, cited above in note (1).

28 See, for example, $G$ 4:428.

\section{References}

Baxley, Anne Margaret

2003 "Autonomy and Autocracy," Kant-Studien 94: 1-23.

Darwall, Stephen

1977 “Two Kinds of Respect," Ethics 88: 36-49.

Dean, Richard

2006 The Value of Humanity in Kant's Moral Theory. New York: Oxford University Press.

Denis, Lara

2010 "Freedom, Primacy, and Perfect Duties to Oneself," Kant's Metaphysics of Morals: A Critical Guide, ed. Lara Denis. Cambridge: Cambridge University Press. 
Engstrom, Stephen

1996 "Happiness and the Highest Good in Aristotle and Kant," Aristotle, Kant, and the Stoics: Rethinking Happiness and Duty. Cambridge: Cambridge University Press.

Guyer, Paul

2000 Kant on Freedom, Law, and Happiness. Cambridge: Cambridge University Press.

2003 "Kant on the Theory and Practice of Autonomy," Social Philosophy and Policy 20: 70-98.

Hill, Thomas

1992 Dignity and Practical Reason in Kant's Moral Theory. Ithaca: Cornell University Press.

2000 Respect, Pluralism, and Justice: Kantian Perspectives. New York: Oxford University Press.

Kant, Immanuel

1780 Lectures on Ethics, ed. and trans. Peter Heath. Cambridge: Cambridge University Press, 2001.

1785 Groundwork of the Metaphysics of Morals, ed. and trans. Mary Gregor. Cambridge: Cambridge University Press, 1998.

1788 The Critique of Practical Reason, ed. and trans. Mary Gregor. Cambridge: Cambridge University Press, 1997.

1793 Religion within the Boundaries of Mere Reason, ed. and trans. Alan Wood and George di Giovanni. Cambridge: Cambridge University Press, 1998.

1797 The Metaphysics of Morals, ed. and trans. Mary Gregor. Cambridge: Cambridge University Press, 1996.

Korsgaard, Christine

1996 Creating the Kingdom of Ends. Cambridge: Cambridge University Press.

Meyer, Michael J.

1989 “Dignity, Rights, and Self-Control," Ethics 99: 520-534.

Paton, Herbert James

1947 The Categorical Imperative. London: Hutchison \& Co.

Selby, Hubert

1957 “Tralala," Last Exit to Brooklyn. New York: Grove Press.

Sensen, Oliver

2009 “Kant's Conception of Human Dignity,” Kant-Studien 100: 309-331.

Timmons, Mark

2002 Moral Theory: An Introduction. Lanham: Rowman and Littlefield.

Wood, Allan

1999 Kant's Ethical Thought. Cambridge: Cambridge University Press.

2008 Kantian Ethics. Cambridge: Cambridge University Press. 